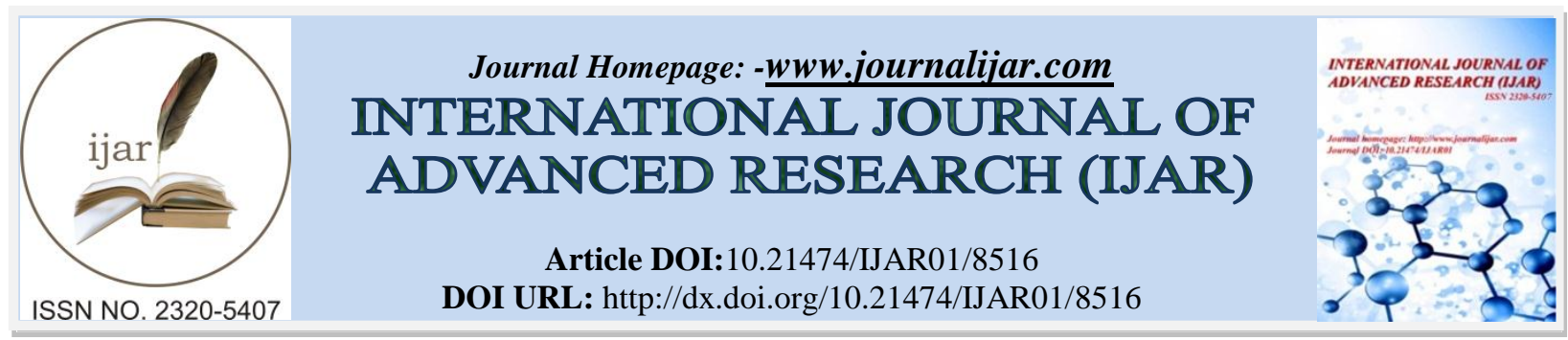

RESEARCH ARTICLE

\title{
PROTECTIVE ROLE OF VITAMIN C ON HISTOPATHOLOGICAL EFFECT OF FORMALDEHYDE ON REPRODUCTIVE SYSTEM IN FEMALE ALBINO MICE (HISTOLOGICAL STUDY).
}

\author{
Soad A. Treesh ${ }^{1}$, Suhera M. Aburawi ${ }^{2}$, Medeha T. Elghedamsi ${ }^{2}$, Habiba A. El Jaafari ${ }^{3}$, Rima Alzowam ${ }^{2}$, \\ Naema Shibani ${ }^{2}$ and Nadia S. Khair ${ }^{4}$. \\ 1. Department of Histology and Medical Genetics, Faculty of Medicine, University of Tripoli, LIBYA. \\ 2. Department of Pharmacology and Clinical Pharmacy, Faculty of Pharmacy, University of Tripoli, LIBYA. \\ 3. Zoology Department, Science Faculty - University of Tripoli, LIBYA. \\ 4. Department of Histology, Faculty of Medicine, Menoufia University, Egypt.
}

\section{Manuscript Info}

\section{Manuscript History}

Received: 06 December 2018

Final Accepted: 08 January 2019

Published: February 2019

Key words:-

Antioxidant, Vitamin C, Formaldehyde, Infertility.

\section{Abstract}

Infertility refers to the biological inability of an individual to contribute to conception, or to a female who cannot carry a pregnancy to full term. Vitamin $\mathrm{C}$ is a water-soluble vitamin that is naturally present in some foods, it is a highly effective antioxidant and used in preventing and treating many disease. Formaldehyde is an organic compound, is used predominantly as a chemical intermediate, disinfectants, fumigants, photography, and wood preservation.

The aim of the study to investigate the protective roles of antioxidants as vitamin $\mathrm{C}$ toward formaldehyde induces damage in female reproductive system.

For this study Female mice $(\mathrm{n}=50,25-40 \mathrm{gm})$ were mated, every 5 female mice with one male mice for 6 days for breeding. On the sixth day female mice were divided into 5 groups: group 1 (control) administered normal saline $(5 \mathrm{ml} / \mathrm{kg}$ ) for 5 days, group 2 received formaldehyde $(30 \mathrm{mg} / \mathrm{kg})$ for 5 days, group 3 received vitamin C $(250 \mathrm{mg} / \mathrm{kg})$ for 5 days, group 4 administered formaldehyde and vitamin $\mathrm{C}$ (prophylactic) for 5 days, group 5 received formaldehyde for 5 days followed by vitamin $\mathrm{C}$ for another 5 days (curative). At the end of 21 days, animals were sacrificed; ovaries and uterus were removed and fixed in $10 \%$ formalin solution for routine histological techniques. Intraperitoneal administration was adopted in this study. It was found that formaldehyde cause reduction in ovulation process and damage in lining endometrial epithelial. Administration of Vitamin $\mathrm{C}$ only increase in ovulation process and showed normal tunica albuginea and also produce hyperstimulation for blood vessels and uterine epithelial. Vitamin C administration for treatment or prophylaxis repair the damage induced by formaldehyde and improves the ovary and uterus to nearly healthy condition. The treated group with vitamin $\mathrm{C}$ showed more repair and improvement compared to the prophylaxis group.

Conclusions: formaldehyde induces histological alteration in ovary and uterus of female mice and in turn, vitamin $\mathrm{C}$ has a prophylaxis and treatment role against the damage induced in female mice. It is recommended for the future work, to find the protective role of vitamin 
$\mathrm{C}$ against formaldehyde induces damage in fetus and offspring; also an investigation, on blood samples, should be carried out on female miceDNA damage that may be caused by formaldehyde and the protective role of vitamin $\mathrm{C}$.

Copy Right, IJAR, 2019,. All rights reserved.

\section{Introduction:-}

1. Infertility refers to the biological inability of an individual to contribute to conception, or to a female who cannot carry a pregnancy to full term [1], [2].

2. According to Mayo Clinic (USA), about $20 \%$ of cases of infertility are due to a problem in the man; about $40 \%$ to $50 \%$ of cases of infertility are due to a problem in the woman; about $30 \%$ to $40 \%$ of cases of infertility are due to problems in both the man and the woman [1].

3. Cause of female infertility may be due to Hormonal Imbalance [3], [4], Thyroid disease, polycystic ovaries syndrome (PCOS), hyperprolactinemia [3], Endometriosis [5], sexually transmitted disease [6] and Pelvic inflammatory disease (PID) [7], [8]. Medications used in chemotherapy can result in ovarian failure. In some cases, this side effect of chemotherapy may be permanent [1],[9]; Women who take NSAIDs (non-steroidal anti-inflammatory drugs) for long-term may find it harder to conceive ;If radiotherapy was aimed near the woman's reproductive organs, there is a higher risk of fertility problems [1].

\section{Vitamin C:}

Is an organic compound [10], also known as L-ascorbic acid; Humans, unlike most animals, are unable to synthesize vitamin $\mathrm{C}$ endogenously, so it is an essential dietary component [11].

Vitamin $\mathrm{C}$ an excellent antioxidant aids in both male and female fertility [12], it may provide a benefit to the human reproductive system through its strong antioxidant properties, where researchers have also suggested that vitamin $C$ plays a very important role in the female reproductive system as well [13]. Vitamin $C$ has been strongly correlated with fertility through its essential role in hormone secretion [14],[15], increases fertility and helps to absorb iron in women with a luteal phase defect [16],gamete production and gonad tissue remodeling [14], [15]. Is known to be essential for collagen synthesis in the body, where in human reproduction, collagen synthesis is important for follicular development (the phase in which follicles in the ovary mature), luteum development and the remodeling of the ovulated follicle [13]. Ascorbic acid supplementation enhanced the ovulation-inducing effects of clomiphene by an apparently local ovarian effect [17].

It sustains an appropriate female endocrine equilibrium [12] and increase serum progesterone levels [17], [18], [19], [20]; these mean increases fertility in particular in the case of women having low progesterone levels. It also reinforces the right balance between estrogen and progesterone levels; where clinical trials on women have proven that the chances of getting pregnant doubled following the vitamin $\mathrm{C}$ treatment [12].

Dietary supplementation of vitamin C during pregnancy may reduce the frequency of birth defects [21], has been suggested for pregnant mothers a daily supplement of at least $500 \mathrm{mg}$ of vitamin C starting as early in pregnancy as possible [22]. Deficiencies in antioxidants during pregnancy have been shown to adversely affect fetoplacental unit development, therefore vitamin $\mathrm{C}$ intake can play a role in protecting fetal tissues from abnormalities [13]. Women should avoid large doses of vitamin $\mathrm{C}$ because it can dry up cervical fluid, preventing sperm from reaching the ova. The recommended daily dose for women is $500 \mathrm{mg}[\mathbf{1 6}]$.

There have been relatively few studies investigating the reproductive and developmental toxicity of formaldehyde. One study noted an increased incidence of menstrual disorders, anemia, toxemia and low birth weight of offspring in female workers exposed to urea formaldehyde [23].

Formaldehyde (FA) is a naturally occurring organic compound with the formula $\mathrm{CH} 2 \mathrm{O}$. It is the simplest aldehyde [24]. There have been relatively few studies investigating the reproductive and developmental toxicity of formaldehyde. One study noted an increased incidence of menstrual disorders, anemia, toxemia and low birth weight of offspring in female workers exposed to urea formaldehyde [23]. Of these studies there is insufficient evidence to determine whether formaldehyde causes reproductive toxicity, due to limitations such as small sample sizes, no information of confounding factors, self-reporting and a lack of information regarding concurrent exposure 
to other potentially harmful compounds [23],[25]. Formaldehyde is not expected to cause reproductive or developmental toxicity at exposures below maternally toxic doses.

\section{Aim of the work:}

The present study was designed to investigate the protective roles of vitamin $\mathrm{C}$ as antioxidant toward formaldehyde induces damage in female reproductive system.

\section{Materials and methods:- \\ Materials}

Vitamin C supplement was obtained from PIS, Tunisia; Formaldehyde, $\mathrm{NaCl}$ and Eosin Y were purchased from Red El-De Haen AG Seelze-Hannover - Germany; Tween 80 obtained from Leicestershire, uk ; formalin prepared by al Hashan pharmacy, Ain Zara-Tripoli-Libya; Calcium chloride dehydrate obtained from BDH limited poole England.

\section{Method:}

Female mice $(\mathrm{n}=50,25-40 \mathrm{gm})$ were mated, every 5 female mice with one male mice for 6 days for breeding. On the sixth day female mice were divided into 5 groups: group 1 (control) administered normal saline $(5 \mathrm{ml} / \mathrm{kg})$ for $5 \mathrm{days}$, group 2 received formaldehyde $(30 \mathrm{mg} / \mathrm{kg})$ for 5 days, group 3 received vitamin C (250mg/kg) for 5 days, group 4 administered formaldehyde and vitamin $\mathrm{C}$ (prophylactic) for 5 days, group 5 received formaldehyde for 5 days followed by vitamin $\mathrm{C}$ for another 5 days (curative). At the end of 21 days, animals were sacrificed; ovaries and uterus were removed and fixed in $10 \%$ formalin solution for routine histological techniques. Intraperitoneal administration was adopted in this study.

\section{Preparation of formalin solution}

$10 \%$ formalin solution was prepared by adding $10 \mathrm{ml}$ formalin and $10 \mathrm{ml}$ of $10 \%$ calcium chloride to $80 \mathrm{ml}$ distilled water. Calcium chloride was prepared by dissolving $10 \mathrm{gm}$ anhydrous $\mathrm{CaCl}_{2}$ in $100 \mathrm{ml}$ distilled water [26], [27].

\section{Histological study}

At the end of the administration, mice were sacrificed; uterus and ovary of treated mice were removed and then were fixed in formalin for 24 hours. The specimens were washed twice with $70 \%$ alcohol. The fixed tissues were dehydrated in an ascending series of alcohol ranging from $70 \%$ to $100 \%$ (absolute). The dehydrated tissues were cleared in xylene (twice), infiltrated and then were embedded in paraffin wax. The uterus or ovary were sectioned on a rotary microtome, sections were $5 \mu \mathrm{m}$ in thickness. The prepared sections were stained by routine methods using Hematoxylin-eosin method [28].

The stained sections - ovaries \& uterus - from each study group were evaluated for structural changes and photographed, blind by a histologist. Light microscopy (Leica, Germany) was used for the evaluations.

\section{Results:- \\ Control group \\ Ovary Control:}

Examination of H\&E- stained sections of control mice's ovary revealed that the ovary was covered by a single layer of cuboidal epithelium (Fig. 1,a). In the ovarian cortex, the primordial follicles were seen underneath the tunica albuginea (Fig.1 a, b).

Different forms of growing follicles were seen in the ovarian cortex, they comprised of primary and secondary follicles (Fig.1, a).The corpus luteum was formed of both granulosa and theca lutein cells which were polyhedral cells containing large spherical nuclei and large amount of vacuolated cytoplasm.

The stroma of the ovary was formed of connective tissue showing collagen fibers and blood vessels (Fig.1, b).

\section{Uterus Control:}

Examination of H\&E- stained sections of control mice's uterus revealed that the mucosal lining of the uterus, is composed of a simple columnar epithelium and a lamina propria. (Fig.1 c, d). The myometrium is composed of inner longitudinal, middle circular, and outer longitudinal layers of smooth muscle (Fig.1, d). 


\section{Formaldehyde Exposure group \\ Formaldehyde Exposure ovaries:}

Sections of the ovary mice injected with FD showed:

Proliferation of the interstitial cells among growing follicles in concomitant with the increase of the thickness of tunica albuginea covering the ovary than those of the control group (Fig. 2 a, b). There was a great number of growing follicles and few numbers of primordial follicles (Fig. 2 a), however numerous dilated blood vessels in interstitial tissue among atretic follicles \& corpora lutea were observed (Fig. 2 c).

The degeneration appeared in different forms; some follicles showed lysis of the primary oocyte and appearance of acidophilic material filling the cavity of follicular antrum (Fig. 2 d). The surrounding granulosa cells showed pyknosis of their nuclei and of their cytoplasm (Fig. 2 e, f). Other follicles were undergone atresia (Fig.2). Normal growing follicle was also seen (Fig. 2, a).

The most striking feature of this group was the presence of engorged blood vessels occupying the ovarian stroma in concomitant with the vacuolation of the interstitial cells (Fig. 2 c).

\section{Formaldehyde Exposure Uterus:}

Alterations in cellular architecture of uterus of FD-treatment groups are shown in Figure (3). Compared to the uteri of control group, uterus of mice treated Characterized by decreased prominence of endometrial glands, less and few uterine glands. Degeneration of luminal epithelium and decrease in its thickness. Cellular vacuolar degeneration (Fig.3 a, b). Most nuclei of glandular and luminal epithelium have heterochromatin. Note congested blood vessel (Fig. 3 b). Distortion and degeneration of luminal epithelium. Necrosis of the endometrial glands. Stromal mitotic figures (Fig.3 c, d).

Proliferative endometrium with a small focus to the gland, some cells within the gland (abortive cells), vacuolar degeneration in endometrial epithelial cells, damage to endometrial glands. In addition, there was sloughing off of the lining endometrial epithelial cells (Fig. 3, b).

\section{Vitamin C group}

\section{Vitamin C exposure ovaries:}

Sections of the ovary mice injected with Vit. C showed:

Normal appearance of tunica albuginea covering the ovary (Fig. 4 a, b). Numerous blood vessels in interstitial tissue among atretic follicles \& corpora lutea were observed (Fig. 4, b).

\section{Vitamin C exposure uterus:}

Sections of the uterus mice injected with Vit. C showed:

A marked thickness of endometrium with hyperplasia \& metaplasia of the uterine epithelial and glandular epithelial, dilated and congested blood vessels well seen (Fig. 4 c, d).

\section{Vitamin C (Prophylaxis) exposure ovaries:}

The ovaries of this group showed the presence of growing follicles but very little of primordial follicle, proliferation of the interstitial cells among growing follicles, tunica albuginea covering the ovary thicker than the control group, numerous dilated blood vessels in interstitial tissue among atretic follicles \& corpora lutea were observed (Fig.5 a ,b).

\section{Vitamin C (Prophylaxis) exposure uterus:}

This group showing more increase in the thickness of luminal epithelium (pseudostratification).Endometrial glands showing branching and outpouching with appearance of secretion in their lumen (Fig. 5 c, d).

\section{Vitamin C (Treatment) exposure ovaries:}

Sections of the ovaries mice injected with Vit. C (as treatment) showed:

Nearly normal appearance of the ovaries, there are no marked changes compared to control group (Fig. 6 a, b).

\section{Vitamin C (Treatment) exposure uterus:}

This group showing nearly normal appearance of glandular and luminal epithelium; the presence of glandular secretion is well seen in the lumen (Fig. $6 \mathrm{c}, \mathrm{d}$ ). 


\section{Discussion:-}

The control group showed healthy ovary, the egg passed all stages, as well as normal uterus and normal number of uterus glands.

In formaldehyde treated group, ovary showed great number of mature follicles and little number of primordial follicles. This means that formaldehyde cause damage that made primordial follicles in unfinished stages; and low number of corpus luteum compared to the control group, this means that formaldehyde cause reduction in ovulation process, because the number of corpus luteum indicate on the amount of ovulation, and also showed proliferation for interstitial cell and increase thickness of tunica albugina and this considered abnormal.

The uterus that exposure for formaldehyde showing sloughing off of lining endometrial epithelial and low number of endometrial glands compared with the control group. The damage that caused by formaldehyde in ovary and uterus may indicate the potential mechanisms underlying formaldehyde-induced reproductive and developmental toxicities, including chromosome and DNA damage (genotoxicity), oxidative stress, altered level and/or function of enzymes, hormones and proteins, apoptosis, toxic genomic and epigenomic effects (such as DNA methylation) [29]; where FA is known genotoxic and mutagenic to mammalian cells and that it induces a broad spectrum of genetic effects [30],[31], [32].

The primary and direct genotoxic effect of FA seems to be the formation of DNA-protein crosslinks (DPC) in target tissues [33]; the exact mechanism of formaldehyde action toxicity is not clear, but it is known that it can interact with molecules on cell membranes (e.g., proteins and DNA) and disrupt cellular functions. High FA concentrations cause precipitation of proteins, which results in cell death [34].

Once absorbed, formaldehyde is oxidized to formic acid and $\mathrm{Co}$, which may cause acid-base imbalance and a number of other systemic defects [34]. Formaldehyde is metabolized to formate and Co2 by formaldehyde hydrogenase (FDH). The toxicity of the metabolite and formaldehyde in humans as well as animals includes metabolic acidosis. Free radical may accumulate with time and through alterations in protein structure and function, these oxidation products may contribute to the development of these changes that occurred in ovary and uterus due to formaldehyde [35]. Ovarian function of female rats can be impaired after subchronically exposed to formaldehyde for 14 days [36].Formaldehyde has adverse effects on estrous cycle and ovary female mice [37].Additionally, it was suggested that the form of DNA damage induced by gaseous FA on reproductive cell of female mice was DPC increased with the increasing of FA concentrations, indicating that gaseous FA has obvious genetic toxicity on the reproductive cells of female mice since DPC is a grievous damage of DNA [38].

Vitamin $\mathrm{C}$ administration showed healthy ovary with normal appearance of tunica albuginea covering the ovary, and high number of corpus luteumcompared to formaldehyde treated group. This mean the vitamin $\mathrm{C}$ stimulate ovulation more than control group and repair the damage induced by formaldehyde. Vitamin C hyperstimulating and dilate blood vessels (in ovary \& uterus) and uterine epithelial compared to the control and formaldehyde group. This indicates the very strong activity of vitamin $\mathrm{C}$. Where vitamin $\mathrm{C}$ is considered effective antioxidant in various biological systems [39], [40], [41], and [42]. Ascorbic acid has three biological actions of particular relevance to reproduction, each dependent on its role as a reducing agent: it is required for the biosynthesis of collagen, for the biosynthesis of steroid and peptide hormones, and to prevent or reduce the oxidation of biomolecules. It is frequently involved in mixed-function oxidation, resulting in the incorporation of oxygen from molecular oxygen into a substrate [43].

The role of ascorbic acid in maintaining the structure of collagenous tissues was confirmed [14]. It is needed for the synthesis of collagen during tissue development and at sites of tissue damage, and also for the maintenance of the slow collagen turnover which occurs in mature tissues [44]. More recent studies with luteinizing granulosa cells show that ascorbate is stimulatory to progesterone and oxytocin secretion [45],[46] ; consistent with its known roles in hormone biosynthesis, and synergizes with neurotransmitters in stimulating hormone secretion [47].Collagen synthesis is required for follicle growth, for repair of the ovulated follicle [48], and for corpus luteum development [49].Ascorbate will also be needed for secretion of collagen and proteoglycans into follicular fluid [50] ,[51],[52].Vitamin C treatment and prophylaxis group showed nearly healthy condition compared to the control group, where it showed primary and secondary and grafian follicles, but the treatment group show better repair and improvement than the prophylaxis group. 
Formaldehyde was found to induce oxidative stress through increasing lipid peroxidation [53], and formation of reactive oxygen species (ROS) and depletion of the antioxidant enzymes such as superoxide dismutase and glutathione peroxidase and also caused destruction of mitochondria [54]. Where reactive oxygen species target is the macromolecules in cells (e.g. lipids, proteins and nucleic acids) and cause peroxidative damage [55].ROS affect multiple physiological processes from oocyte maturation to fertilization. Ovulation induced oxidative base damage to DNA of the ovarian epithelium can be prevented by antioxidant [56]. Since vitamin c is considered as a strong antioxidant compound that can strongly scavenge free radicals especially ROS [57], [41].

Vitamin $\mathrm{C}$ was shown to act as a chain breaking scavenger for peroxy radicals [58], Ascorbic acid may also prevent gametes from damage by free radicals during reproduction and fertilization [59]. Where vitamin $\mathrm{C}$ it is needed for the synthesis of collagen during tissue development and at sites of tissue damage[44], and Collagen synthesis is required for follicle growth, for repair of the ovulated follicle [48], and for corpus luteum development [49],[60] studied the ischemic tissue damage in ovarian cortex and to evaluate the effectiveness of ascorbic acid and antioxidant to protect ovarian tissue from apoptosis, where found ovarian cortex could tolerate ischemia at least for 3 hours and Ascorbic acid treatment reduced apoptosis in ovarian cortex up to 24 hours of incubation in vitro [60].Murry et al. reported that ascorbic acid is necessary for remodeling the basement membrane during follicular growth and that the ability of follicles to uptake ascorbic acid confers an advantage in terms of granulosa cell survival [61].

\section{Conclusion:-}

Based on the findings of this study, it can be concluded that formaldehyde induce histological alteration in ovary and uterus of female mice reproductive system and in turn, vitamin $\mathrm{C}$ has prophylaxis and treatment role against this damage induced by formaldehyde.

\section{Future of work:}

Future studies on animal models will provide novel information on protective role of vitamin $\mathrm{C}$ against formaldehyde damage in fetus and offspring; also to investigate DNA damage induced by formaldehyde, using blood samples of female mice (mother).

\section{Acknowledgements:-}

This study was supported by the project titled; the protective effect of antioxidants; selenium, vitamin C and vitamin $\mathrm{E}$ on infertility induced by formaldehyde using female albino mice under supervision of professor Suhera Aburawi , Department of Pharmacology and Clinical Pharmacy, Faculty of Pharmacy, University of Tripoli, LIBYA.

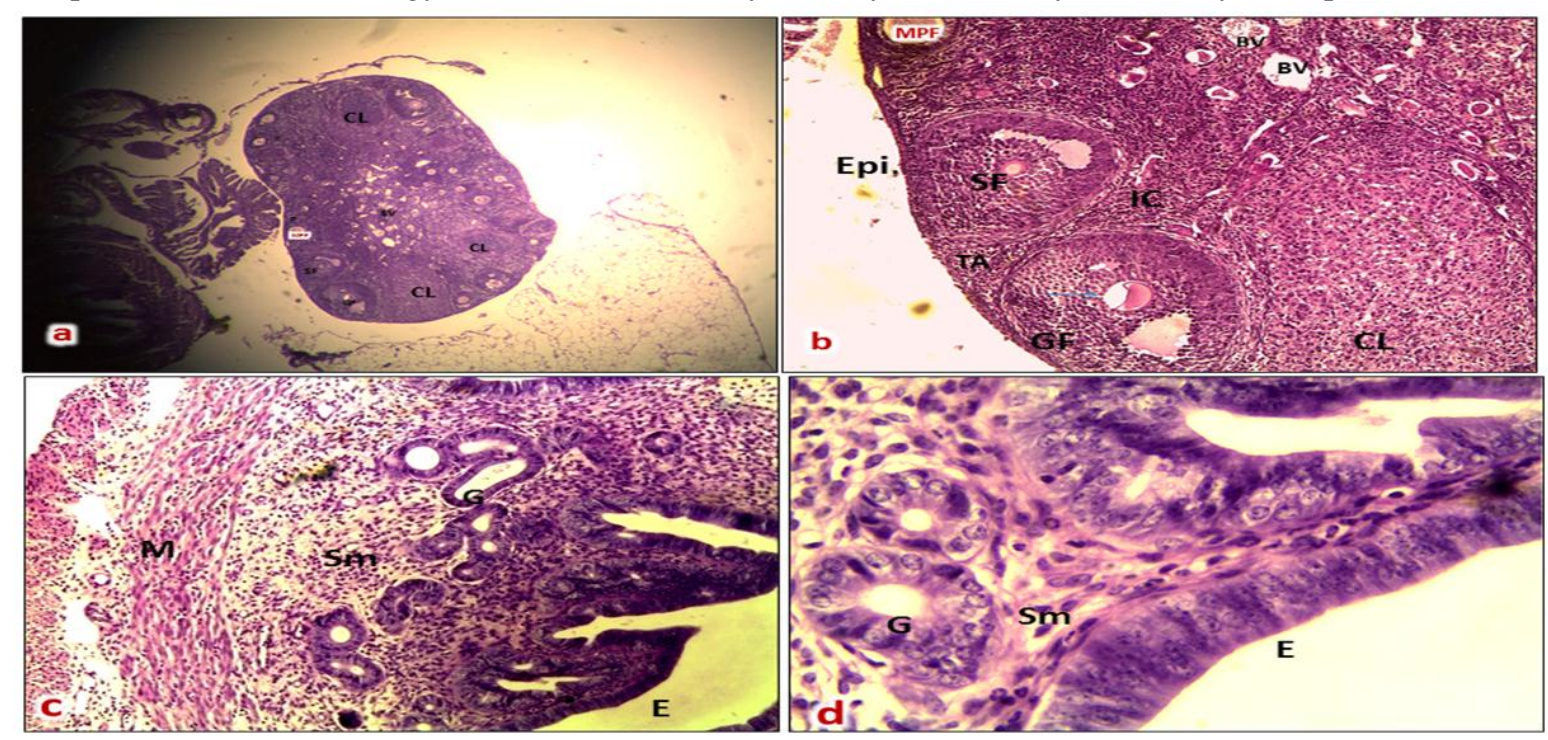

Figure 1:-A photomicrograph of control mice ovary and uterus showing; 
1. Overview of control ovary showing primordial follicle (P), corpus luteum (CL) (H\&E, 2.5X).

2. A single layer of cuboidal surface epithelium (E), underneath it an aggregates of interstitial cells (IC) are found. Note the presence of tertiary follicle (GF), well defined corona radiate (arrow) (H\&E, 10 xs).

3. Normal histological features of endometrium containing lining epithelium of simple columnar (E), uterine glands $(\mathrm{G})$ and Myometrium (M), (H\&E, 10X).

4. Endometrium contains smooth muscle $(\mathrm{Sm})$ in interstitium and uterine glands $(\mathrm{G})(\mathbf{H} \& \mathbf{E}, \mathbf{4 0 X})$.
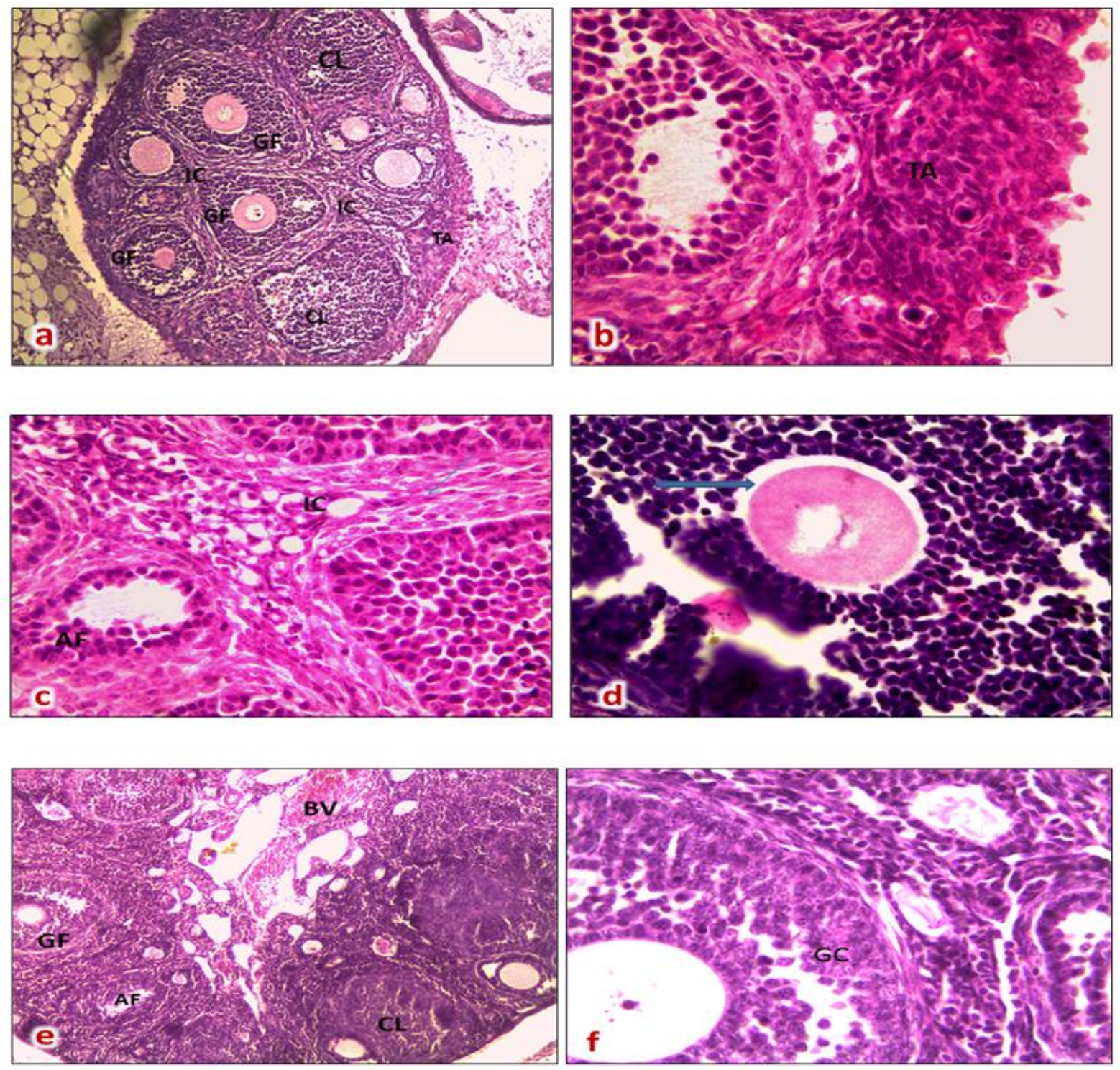

Figure 2:-photomicrographs of FD treated mice ovaries showing

1. Denoting proliferation of the interstitial cells among growing follicles (IC) (H\&E, 10X).

2. A thickening of Tuicaalbuginea (TA), (H\&E, 10X).

3. Numerous blood vessels in interstitial tissue (IC) among atretic follicles (AF) (H\&E, $40 \mathrm{xs}$ ).

4. Lysis of the primary oocyte and appearance of acidophilic material filling the cavity of follicular antrum (H\&E, $40 \mathrm{xs})$.

5. \& f) pyknosis of nuclei and cytoplasm of granulosa cells (H\&E, 40x). 

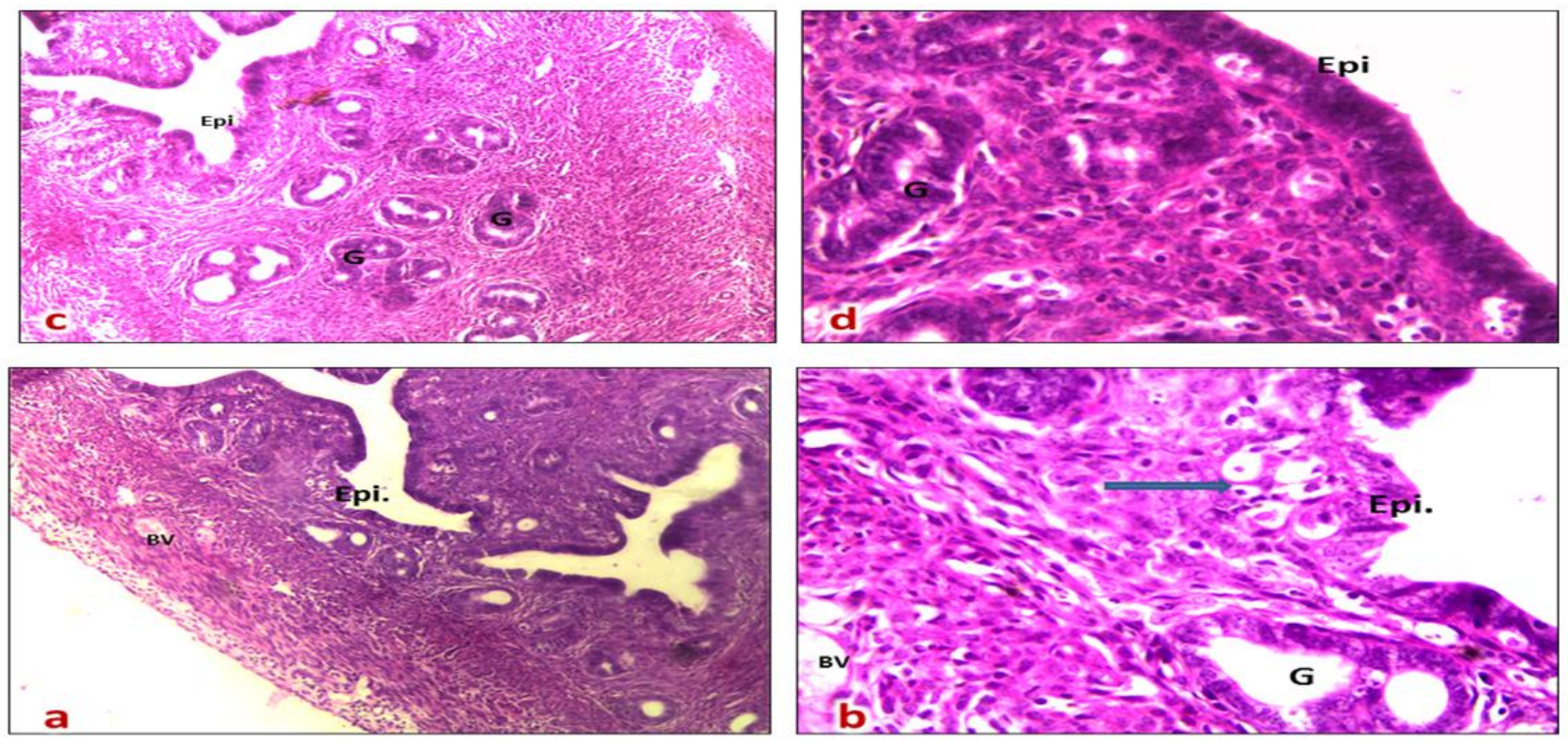

Figure 3:-photomicrographs of mice uterus treated with FD showing

1. Endometrium showing decreased prominence of endometrial glands, congested blood vessels (BV) (H\&E, 10X)

2. Vacuolar degeneration in endometrial epithelial cells (arrow), damage of endometrial glands (G), congested blood vessels (BV) (H\&E, $40 \mathrm{xs})$.

3. Sloughing off of the lining endometrial epithelial (Epi.) (H\&E, $10 \mathrm{xs})$.

4. Higher magnification of previous figure showing degeneration of glandular epithelium $(\mathrm{G})$ \& vacuolar degeneration in endometrial epithelial cells (Epi.) (H\&E, $40 \mathrm{xs}$ ).
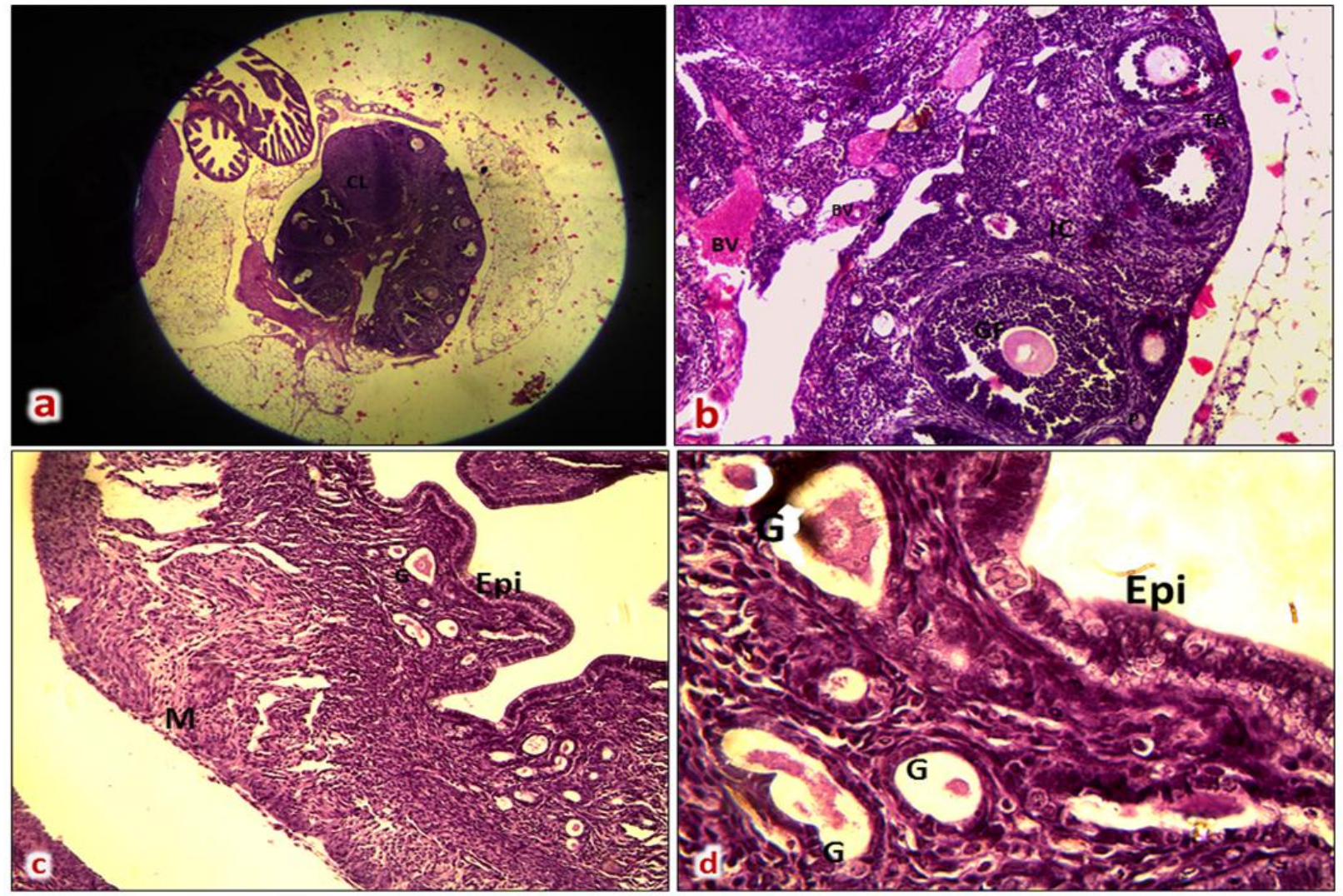

Figure 5:-photomicrographs of mice ovary \& uterus treated with FD \&Vit.C (prophylaxis) showing; 
1. A photomicrograph of mice ovary contain growing follicles (GF) and primordial follicle (P), (H\&E, 2.5X).

2. Slightly thickness of tunica albuginea (TA), growing follicles (GF), interstitial cells (IS), dilated blood vessels in interstitial tis $(\mathrm{BV}),(\mathrm{H} \& \mathrm{E}, 10 \mathrm{x})$.

3. The endometrium containing little uterine glands contain secretion in their lumen, (H\&E, $10 \mathrm{xs}$ ).

4. Higher magnification of previous figure showing proliferation of uterine epithelium, pseudostratification (Epi.) (H\&E, $40 \mathrm{xs})$.
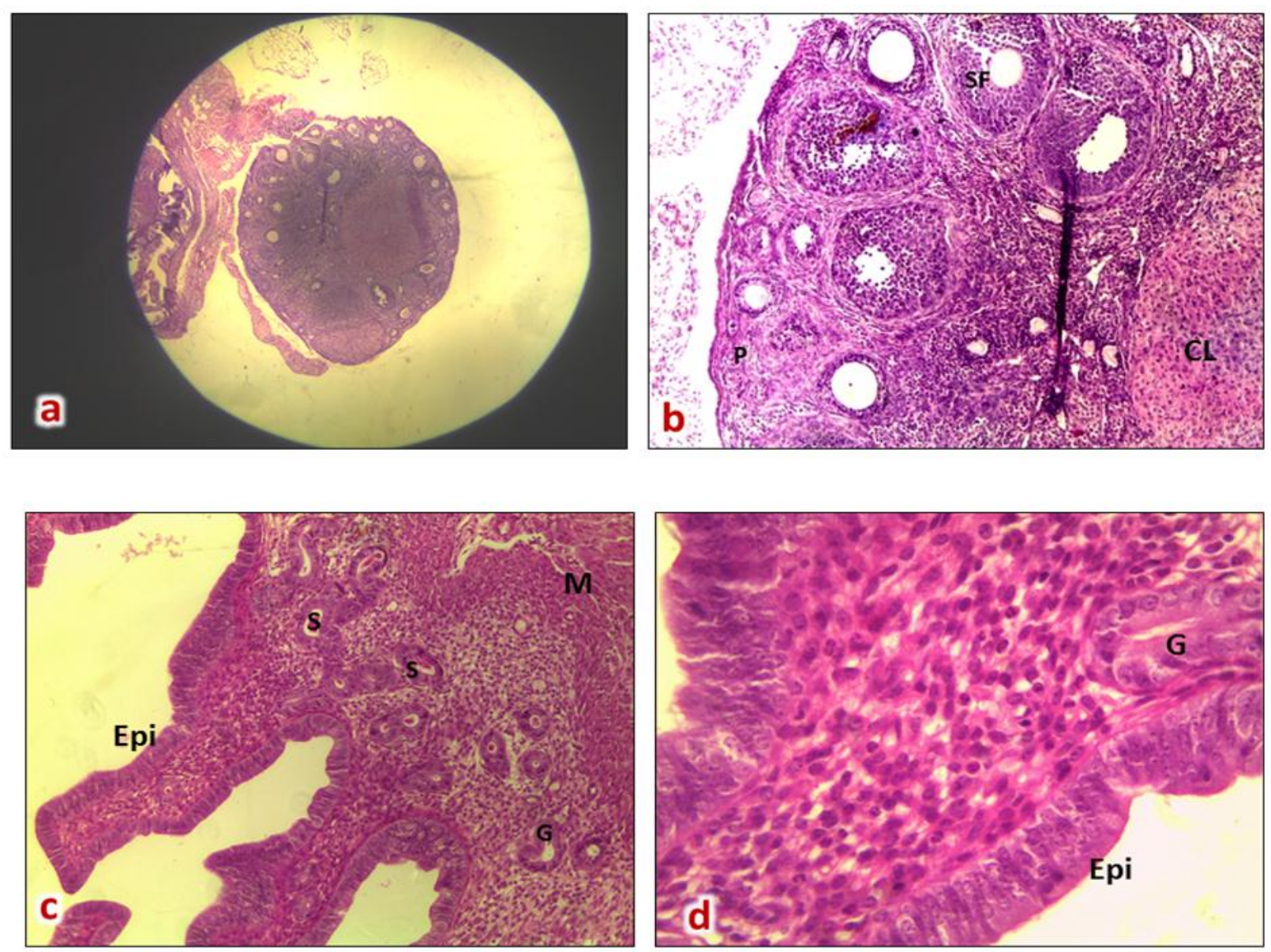

Figure 6:-photomicrographs of mice ovary \& uterus treated with FD \& then with Vit. C (treatment) showing;

1. Ovary appears nearly normal (H\&E, $2.5 \mathrm{xs})$.

2. Presence of primordial follicle (P), secondary follicle (SF), corpusletum (CL), (H\&E, 10x).

3. Normal uterine epithelial projections (Epi.), normal appearance of myometrium (M), the presence of glandular secretion (S) (H\&E, $10 \mathrm{xs})$.

4. Higher magnification of previous figure showing normal uterine gland $(G) \&$ normal epithelium (Epi.) (H\&E, $40 \mathrm{xs})$.

\section{Reference:-}

1. Nordqvist C., "Infertility: Causes, Diagnosis, Risks, Treatments", Last updated: ( 2016 ) http://www.medicalnewstoday.com/articles/165748.php

2. Mosher WD, Bachrach CA. (1996), "Understanding U.S. fertility: continuity and change in the National Survey of Family Growth", 1988-1995. FamPlannPerspect; 28:4-12.http://www.aafp.org/afp/2007/0315/p849.pdf

3. Legro RS. (2007), "A 27-year-old woman with a diagnosis of polycystic ovary syndrome". JAMA 297 (5):509519. Doi: 10.1001/jama.297.5.509. PMID 17284701 
4. Gohill BC, Rosenblum LA, Coplan JD, Kral JG. CNS Spectr., (2001),"HypothalamiC-PituitaryADRENAL AXIS FUNCTION AND THE METABOLIC SYNDROME X OF OBESITY"6(7): PP 581586.HTTP://WWW.NCBI.NLM.NIH.GOV/PUBMED/15573024

5. Tomassetti C, Meuleman C, Pexsters A, Mihalyi A, Kyama C, Simsa P et al. (2006), "Endometriosis, RECURRENT MISCARRIAGE AND IMPLANTATION FAILURE: IS THERE AN IMMUNOLOGICAL LINK?", REPROD BIOMED ONLINE, 13 (1): 58-64.

6. AMERICAN SOCIETY FOR REPRODUCTIVE MEDICINE (ASRM). (2009), "FERTILITY FACT > FEMALE RISKS".

7. SENANAYAKE SN. Med J AUSt, (2008), "MumPS: A RESURGENT DisEASE WiTH PROTEAN MANIFESTATIONS", 189 (8): 456-9. HTTP://WWW.NCBI.NLM.NIH.GOV/PUBMED/18928441.

8. Guven MA, Dilek U, Pata O, Dilek S, Ciragil P. (2007), "Prevalence of Chlamydia trochomatis, Ureaplasmaurealyticum and Mycoplasma hominis infections in the unexplained infertile women". Arch. Gynecol. Obstet. 276 (3):219-23.

9. Rosendahl M, Andersen C, Freiesleben NL, Juul A, Løssl K, Andersen A. (2010), "Fertility and sterility",94(1): 156-166.

10. Nordqvit j. "What is vitamin c? How much vitamin c do you need?", last updated: 17 September (2014). http://www.medicalnewstoday.com/articles/219352.php.

11. Li Y,Schellhorn HE. (2007), "New developments and novel therapeutic perspectives for vitamin c". J Nutr;137:2171-84.http://jn.nutrition.org/content/137/10/2171.long

12. Scott M, BS, RN. (2012),"Fertility Vitamins: 8 Vitamins to Get Pregnant". http://www.conceiveeasy.com/getpregnant/fertility-vitamins/

13. ADMIN 23 ${ }^{\mathrm{RD}}$ (2013),"Vitamin C Benefits: A Comprehensive Look". http://nutrition.about.com/od/nutrition101/f/What-Are-Antioxidants-Good-For.htm.

14. Davis MB, Austin J, Partridge DA. (1991), "Vitamin C: Its Chemistry and Biochemistry". Cambridge: Royal Society of Chemistry. http://www.biolreprod.org/content/52/2/262.full.pdf

15. Franceschi RT. (1992), "The role of ascorbic acid in mesenchymal differentiation". Nutr Rev 50:65-70.

16. Langham R. Y, Ph.D. "Can Certain Vitamins Increase Fertility in Women?", Last Updated: Oct 30, (2013). http://www.livestrong.com/article/105124-vitamins-increase-fertility-women/

17. Igarashi M. (1977), "Augmentative effect of ascorbic acid upon induction of human ovulation in Clomipheneineffective anovulatory women". Int J Fertile 22:168-173.

18. Henmi H, Endo T, Kitajima Y et al. (2003), "Effects of ascorbic acid supplementation on serum progesterone levels in patients with a luteal phase defect". FertilSteril 80:459-461.

19. Tannetta D, Sargent I, Linton E et al. (2008), "Vitamins C and E Inhibit Apoptosis of Cultured Human Term Placenta Trophoblast". Placenta 29:680-690.

20. Luck M, Jeyaseelan I, Scholes R. (1995), "Ascorbic acid and fertility". BiolReprod 52:262-266.

21. Nelson MM, Forfar JO. (1971), "Epidemiology of drugs taken by pregnant women: drugs that may affect the fetus adversely". ClinPharmacol, 14:632-642.

22. Wilson CWM, Loh HS. (1973), "Vitamin C and fertility". Lancet 2:859-860.

23. International Programme on Chemical Safety (IPCS). (1989), "Formaldehyde". Environmental Health Criteria 89. WHO. Geneva.

24. Reuss G, Disteldorf W, Gamer A, Hilt A. (2002), "Formaldehyde in Ullmann'sEncyclopediaofIndustrialChemistry", Wiley-VCH, Weinheim. doi:10.1002/14356007.a11_619.https://dx.doi.org/10.1002\%2F14356007.a11_619.

25. Canadian Centre for Occupational Health and Safety (CCOHS). (2004), "Formaldehyde gas", Cheminfo https://www.gov.uk/government/uploads/system/.

26. Baker, J.R. (1958), "Principles of biological Technique". London: Methuen; New York: John Wiley.

27. Humason, L.G. (1979), "Animal Tissue Techniques", $4^{\text {th }}$ ed. W.H. Freeman and Company, San Francisco.

28. Bancroft JD, Gamble M. (2002), "Theory and practice of histological techniques", $5^{\text {th }}$ ed. Philadelphia: Churchill Livingstone; pp. 125-138.

29. Duong A, SteinmausC, McHale CM, Vaughan CP, and Zhang L. (2011), "Reproductive and Developmental Toxicity of Formaldehyde: A Systematic Review", Published in final edited form as: Mutat Res. 2011 Nov; 728(3): 118-138. Published online $2011 \quad$ Jul 20. Doi: 10.1016/j.mrrev.2011.07.003http://www.ncbi.nlm.nih.gov/pmc/articles/PMC3203331/.

30. International Agency for Research on Cancer (IARC). (1995), "Monographs on the evaluation of carcinogenesis risks to humans: Wood dust and formaldehyde". No. 62. Lyon, France: IARC, 217-375.

31. Ma TH, Harris MM. (1988), "Review of the genotoxicity of formaldehyde". Mutat; 196:37-59. 
32. Conaway CC, Whysner J, Verna LK, et al. (1996), "Formaldehyde mechanistic data and risk assessment: endogenous protection from DNA adducts formation". Pharmacol Ther71:29-55.

33. Nishioka H. (1973), "Lethal and mutagenic action of formaldehyde in $\mathrm{HCr}^{+}$and $\mathrm{HCr}^{-}$strains of Escherichia coli". Mutat Res17:261-5.

34. Agency for Toxic Substances and Disease Registry (ATSDR). (2008), "Toxicological profile for Formaldehyde". (Draft for Public Comment). Atlanta, GA: U.S. Department of Health and Human Services, Public Health Service.

35. Ballinger SC, Couder TB and Davis GS. (1996), "Mitochondrial genome damage associated with cigarette smoking". Cancer Research. 56: 5692-5697.

36. Peng, G.Q., Zhong .C.G, Zhang. Q, Guan. L, J. Y. Yu and Xiao. F. (2010), "Effects of formaldehyde on ovarian reserve function in female rats". Carcinogenesis Teratogenesis Mutagen, 22: 32-34.

37. Wang, W, Tang .M, Yi .Y and Xie .Y. (2002), "The effects of formaldehyde on estrous cycle and ovary of female mice". Pract. Prev. Med., 9: 641-643.

38. Liu, D. and Wang.B. (2006), "Study on DNA-Protein crosslinks of reproductive cell of female mice induced by formaldehyde". Asian J. Ectoxicol., 1: 249-253.

39. Chen K, Suh J, Carr AC, Morrow JD, Zeind J, Frei B. (2000), "Vitamin C suppresses oxidative lipid damage in vivo, even in the presence of iron overload". Am J Physiol, EndocrinolMetab, 279(6): 1406-1412?

40. Frei B. (2004), "Efficacy of dietary antioxidants to prevent oxidative damage and inhibit chronic disease". J Nutr, 134 (Suppl.): 3196-3198.

41. Ayo J, Minka N, and Mamman M. (2006), "Excitability scores of goats administered ascorbic acid and transported during hot-dry conditions". J Vet Sc 7, 127-131.

42. Ambali S, Akanbi D, Igbokwe N, Shittu M, Kawu M, Ayo J. (2007), "Evaluation of subchronicchlorpyriphos poisoning on haematological and serum biochemical changes in mice and protective effect of vitamin $\mathrm{C}$ ". The $\mathrm{J}$ ToxicolSc, 32 (2): 111-120.

43. Sebrell WH, Harris RS. (1967), "The Vitamins, Chemistry, Physiology, Pathology and Methods". Vol. 1. New York: Academic Press; 305-320.

44. Hulmes DJS. (1992), "The collagen superfamily--diverse structures and assemblies". Essays Biochem 27:49-67.

45. Luck MR, Jungclas B. (1988), "The time course of oxytocin secretion from cultured bovine granulosa cells, stimulated by ascorbate and catecholamines". J Endocrinol: 116:247-258.

46. Byrd JA, Pardue SL, Hargis BM. (1993), "Effect of ascorbate on luteinizing hormone stimulated progesterone biosynthesis in chicken granulosa cells in vitro". Comp BiochemPhysiol; 104A:279-281.

47. Luck MR. (1990), "Cholinergic stimulation, through muscarinic receptors, of oxytocin and progesterone secretion from bovine granulosa cells undergoing spontaneous luteinization in serum-free culture". Endocrinology; 126:1256-1263.

48. Himeno N, Kawamura N, Okamura H, Mori T, Fukomoto M, Midorikawa O. (1984), "Collagen synthetic activity in rabbit ovary during ovulation and its blockage by indomethacin".ActaObstetGynaecolJpn ; 36:19301934.

49. Luck MR, Zhao Y. (1993), "Identification and measurement of collagen in the bovine corpus luteum and its relationship with ascorbic acid and tissue development". J ReprodFertil; 99:647-652.

50. Christiane Y, Demoulin A, Gillain D, Leroy F, Lambotte R, Lapiere CM, Nusgens B, Foidart J-M. (1988), "Laminin and type III procollagen peptide in human preovulatory follicular fluid". FertilSteril ; 50:48-51.

51. Kao J, Huey G, Kao R, Stern R. (1990), "Ascorbic acid stimulates production of glycosaminoglycans in cultured fibroblasts". ExpMolPathol; 53:1-10.

52. Fisher E, McLennan SV, Tada H, Heffernan S, Yue DK, Turtle JR. (1991),"Interaction of ascorbic acid and glucose on production of collagen and proteoglycan by fibroblasts". Diabetes; 40:371-376.

53. Pekmez H, Colakoglu C, Zorarsiz D, Kus D, Geturk M, Yilmaz H, Sarsilmaz M. (2008), "The Effect of Melatonin Hormone on Formaldehyde-Induced Liver Injury: A Light Microscopic and Biochemical Study". Firat Tip Dergisi, 13(2) :92-97

54. Zararsiz I, Sarsilmaz M, Tas U, Kus I, Meydan S, and Ozan E. (2007), "Protective effect of melatonin against formaldehyde-induced kidney damage in rats". ToxicolInd Health. 23(10), 573-9.

55. Agarwal A, Saleh RA. (2002), "Role of oxidants in male infertility: rationale, significance, and treatment". Urological Clinics of North America29, 817-827.

56. Agarwal, A., Gupta, S. and Sharma, R.K. (2005), "Role of oxidative stress in female reproduction". ReprodBiolEndocrinol, Jul 14; 3(1):28.

57. Son E, Mo S, Rhee D et al. (2004), "Vitamin C blocks TNF-alphainducedNFkappa B activation And ICAM-1 expression in human neuroblastoma cells". Arch Pharmacol Res 27, 1073-1079. 
58. Stocker, R. and Frei, B. (1991), "Endogenous antioxidant defences in human blood plasma". In: Oxidative Stress (Sies, H. ed.), pp.213-243. Academic Press, London.

59. Sharma R, Qureshi N, Mogra S and Panwar K. (2012), "Lead Induced Infertility in Swiss Mice and Role of Antioxidants". Universal Journal of Environmental Research and Technology Volume 2, Issue 2: 7282:www.environmentaljournal.org.

60. Kim, S.S., Yang, H.W., Kang, H.G., Lee, H.H., Lee, H.C., Ko, D.S. and Gosden, R.G. (2004), "Quantitative assessment of ischemic tissue damage in ovarian cortical tissue with or without antioxidant (ascorbic acid) treatment".FertileSteril, Sep.,82(3): 679-85.

61. Murray, A.A., Molinek, M.D.,Baker, S.J., Kojima, F.N., Smith, M.F., Hillier, S.G. and Spears, N. (2001), "Role of ascorbic acid in promoting follicle integrity and survival in intact mouse ovarian follicles in vitro".Reproduction, Jan; 121(1): 89-96. 